\title{
MET Gene Mutation
}

National Cancer Institute

\section{Source}

National Cancer Institute. MET Gene Mutation. NCI Thesaurus. Code C39788.

A change in the nucleotide sequence of the MET gene. 